\title{
Electrophoretic characterization of protein interactions suggesting limited feasibility of accelerated shelf-life testing of ultra-high temperature milk
}

\author{
Manpreet Kaur Grewal, ${ }^{*}$ Jayani Chandrapala, ${ }^{*}$ Osaana Donkor, ${ }^{*}$ Vasso Apostolopoulos, $\dagger$ \\ and Todor Vasiljevic ${ }^{* 1}$ \\ *Advanced Food Systems Research Unit, and \\ †Immunology in Chronic Diseases Program, Centre for Chronic Disease, College of Health and Biomedicine, Victoria University, Melbourne, \\ VIC 8001, Australia
}

\begin{abstract}
Accelerated shelf-life testing is applied to a variety of products to estimate keeping quality over a short period of time. The industry has not been successful in applying this approach to ultra-high temperature (UHT) milk because of chemical and physical changes in the milk proteins that take place during processing and storage. We investigated these protein changes, applying accelerated shelf-life principles to UHT milk samples with different fat levels and using native- and sodium dodecyl sulfate-PAGE. Samples of UHT skim and whole milk were stored at $20,30,40$, and $50^{\circ} \mathrm{C}$ for $28 \mathrm{~d}$. Irrespective of fat content, UHT treatment had a similar effect on the electrophoretic patterns of milk proteins. At the start of testing, proteins were bonded mainly through disulfide and noncovalent interactions. However, storage at and above $30^{\circ} \mathrm{C}$ enhanced protein aggregation via covalent interactions. The extent of aggregation appeared to be influenced by fat content; whole milk contained more fat than skim milk, implying aggregation via melted or oxidized fat, or both. Based on reduction in loss in absolute quantity of individual proteins, covalent crosslinking in whole milk was facilitated mainly by products of lipid oxidation and increased access to caseins for crosslinking reactions. Maillard and dehydroalanine products were the main contributors involved in protein changes in skim milk. Protein crosslinking appeared to follow a different pathway at higher temperatures $\left(\geq 40^{\circ} \mathrm{C}\right)$ than at lower temperatures, making it very difficult to extrapolate these changes to protein interactions at lower temperatures.
\end{abstract}

Received April 5, 2016.

Accepted September 17, 2016.

${ }^{1}$ Corresponding author: todor.vasiljevic@vu.edu.au
Key words: storage, aggregation, protein interactions, ultra-high temperature, whole and skim milk

\section{INTRODUCTION}

Production of UHT milk involves heating the milk to a high temperature (usually 130 to $140^{\circ} \mathrm{C}$ ) for 3 to $5 \mathrm{~s}$, followed by aseptic packaging to produce a commercially sterile product with minimal changes in quality (Holland et al., 2011). Thermal treatment enables storage of UHT milk at room temperature for up to 9 mo, eliminating the need for refrigeration in the distribution chain. Its long shelf life at room temperature has made UHT milk an important food product from nutritional, technological, and economic points of view. However, high temperature treatment induces changes such as whey protein denaturation, Maillard reaction, and mineral imbalances, which may lead to changes in protein-protein interactions and result in physical storage instabilities, including sedimentation of proteinaceous material at the bottom of the storage container, gel formation (age gelation), or both (Andrews and Cheeseman, 1972; McMahon, 1996; Deeth and Lewis, 2016). Proteolysis, another underlining mechanism of gelation, also involves protein network formation (i.e., interaction or linking between proteins or their fragments; Deeth and Lewis, 2016). Irrespective of mechanism, gelation or sedimentation appears to be governed and preceded by changes in the extent and nature of interactions among milk proteins.

Changes in protein interactions primarily involve noncovalent interactions, via either weak bonding (such as hydrophobic, van der Waals, or electrostatic interactions) or covalent crosslinking with other proteins through formation of disulfide bonds, advanced Maillard products (AMP), and dehydroalanine (Singh, 1991; Friedman, 1999; Wang et al., 2010; Holland et al., 2011). In addition to protein-protein linking, the role of protein-lipid interactions in the initiation and buildup 
of sediment or gel has not been studied extensively. However, several reports have reported on the lower extent of proteolysis (López-Fandiño et al., 1993; Garcia-Risco et al., 1999), and the creation of products of Maillard reaction (AMP; Valero et al., 2001) in stored UHT milk with higher fat content indicates that fat may play some role in the extent of protein interactions during storage.

Exploring the progression and extent of changes in protein interactions by applying full-length shelf-life tests would be time- and resource-intensive. Accelerated shelf-life tests could be a suitable alternative for predicting storage changes in products such as UHT milk. In fact, by accelerating the rate of deterioration of sensory attributes by exposing the product to elevated storage temperatures, shelf life has been predicted in a comparably short time (Richards et al., 2014). Besides deterioration in sensory attributes, protein-protein interactions are also enhanced at higher storage temperatures (Al-Saadi and Deeth, 2008). Therefore, using elevated storage temperatures, protein interactions could also be accelerated, and the results could then be extrapolated to predict aggregation mechanisms at lower storage temperatures using a rapid method of determination such as Fourier transform infrared spectroscopy, avoiding lengthy real-time analysis. However, as has been previously reported, higher storage temperatures $\left(\geq 40^{\circ} \mathrm{C}\right)$ inhibit age gelation (Kocak and Zadow, 1985; McMahon, 1996; Deeth and Lewis, 2016). The reasons for this are not known, but a few suggestions have been postulated. First, an increased rate of proteolysis at higher temperatures results in extensively degraded proteins, which are no longer able to form a stable gel matrix (Datta and Deeth, 2001). The second hypothesis is that accelerated Maillard browning reactions at higher temperatures block lysine residues, which would likely participate in protein-protein interactions leading to gelation (Samel et al., 1971; Gaucher et al., 2008). Third, higher rates of chemical crosslinking via Maillard and other reactions prevents the release of $\beta \kappa$ complex from the micelle, which is the starting point for the onset of age gelation (McMahon, 1996). Furthermore, high storage temperatures slow gelation but result in increased nondispersible sediment (Nieuwenhuise and van Boekel, 2003). Thus, accelerated shelf-life testing in UHT milk could only be used to predict sedimentation at room temperature.

The present study was aimed at establishing the feasibility of using elevated temperatures during storage of UHT milk with different fat contents to predict changes in the interactions of milk proteins that may lead to sedimentation at room temperature.

\section{MATERIALS AND METHODS}

\section{Materials}

Commercial UHT whole (full cream) milk (WM) and skim milk (SM) were provided by a local manufacturer (Murray Goulburn Co-operative Co. Ltd., Victoria, Australia). All milk packs originated from the same batches. Both SM and WM packs were produced on the same day using an established process on an indirect tubular processor (SPX Flow Technology, Mulgrave, Australia) with a $9,000 \mathrm{~L} / \mathrm{h}$ capacity at $138^{\circ} \mathrm{C}$ for $6 \mathrm{~s}$. The composition of the WM as reported by the manufacturer was $33 \mathrm{~g} / \mathrm{L}$ protein, $34 \mathrm{~g} / \mathrm{L}$ fat, 53 $\mathrm{g} / \mathrm{L}$ sugars, $0.55 \mathrm{~g} / \mathrm{L}$ sodium, and $1.2 \mathrm{~g} / \mathrm{L}$ calcium. The composition of the SM was $34 \mathrm{~g} / \mathrm{L}$ protein, $1 \mathrm{~g} / \mathrm{L}$ fat, $53 \mathrm{~g} / \mathrm{L}$ sugars, $0.55 \mathrm{~g} / \mathrm{L}$ sodium, and $1.2 \mathrm{~g} / \mathrm{L}$ calcium.

The electrophoresis chemicals were obtained from Bio-Rad Laboratories (Richmond, CA). The reducing agent 2-mercaptoethanol, bovine milk standards $\alpha$-LA, $\beta-L G$, and BSA were purchased from Sigma (Castle Hill, NSW, Australia). Prestained SDS-PAGE standard (SeeBlue Plus2) was procured from Thermo Fisher Scientific (Scoresby, Victoria, Australia).

\section{Storage of UHT Milk}

The UHT milk packs were stored at room temperature $\left(20^{\circ} \mathrm{C}\right)$ and 3 elevated temperatures $(30,40$, and $50^{\circ} \mathrm{C}$ ) for $28 \mathrm{~d}$ in incubators (Thermoline Scientific Pty Ltd., Wetherill Park, NSW, Australia). The elevated storage temperature served to accelerate the development of storage instabilities. Milk packs were analyzed on the first day of delivery ( $\mathrm{d} 0$ ), and then at two 2 -wk intervals (14 and $28 \mathrm{~d}$ ) during storage for change in the interactions of milk proteins.

\section{Electrophoretic Analysis of Changes in Protein Interactions}

We investigated changes in the interactions of milk proteins during storage of UHT milk using gel electrophoresis - native- and SDS-PAGE under reducing and nonreducing conditions, as previously described (Dissanayake et al., 2013), with some minor modifications. For native-PAGE, milk from each pack was diluted with the native sample buffer $[0.11 M$ Tris- $\mathrm{HCl}$ buffer ( $\mathrm{pH} 6.8), 8.8 \%$ (vol/vol) glycerol, $2.22 \%$ ( $\mathrm{vol} / \mathrm{vol}$ ) of $0.4 \%$ (wt/vol) bromophenol blue solution]. A working volume of $10 \mu \mathrm{L}$ was then loaded on $12.5 \%$ gels and run for $85 \mathrm{~min}$ at $210 \mathrm{~V}$ and $70 \mathrm{~mA}$ in a Protean II xi cell (Bio-Rad Laboratories), filled with tank buffer solu- 
tion (0.025 $M$ Tris, $0.19 M$ glycine, $\mathrm{pH}$ 8.3). Gels were rinsed in MilliQ water for $15 \mathrm{~min}$ and stained using staining solution (0.15\% Coomassie Brilliant Blue R250 dye, $72 \%$ isopropanol, and $3 \%$ acetic acid) by slowly shaking for $1 \mathrm{~h}$. The stain was completely removed, and the gel was destained by shaking it slowly in destaining solution (10\% isopropanol, 10\% acetic acid) overnight on a shaking platform.

The same protocol used for native-PAGE was followed for SDS-PAGE, except that we used an SDS sample buffer $[0.0625 M$ Tris-HCl buffer $(\mathrm{pH} 6.8), 10 \%$ ( $\mathrm{vol} / \mathrm{vol})$ glycerol, $2.5 \%$ (vol/vol) of $0.4 \%$ (wt/vol) bromophenol blue solution, $20 \%$ (vol/vol) of $10 \%$ (wt/vol) SDS]. In reducing SDS-PAGE, $20 \mu \mathrm{L}$ of 2-mercaptoethanol was added per $1 \mathrm{~mL}$ of milk and SDS buffer mix, vortexed, heated in a boiling water bath for 5 min, and cooled before running on SDS-PAGE gels in SDS running buffer (0.1\% SDS, $0.025 M$ Tris, and $0.191 M$ glycine, $\mathrm{pH}$ 8.6). We used prestained SDS-PAGE standard (3-200 kDa) to compare molecular weights. Milk samples from different packs were analyzed in duplicate. Representative gel patterns are shown in Figures 1 to 3. Native-PAGE and SDS-PAGE gels were scanned using a ChemiDoc imager (Chemidoc MP; Bio-Rad Laboratories).

\section{Quantitation and Kinetics of Changes in Protein Interactions}

We determined the intensities of the major protein bands in reducing SDS-PAGE using the Image Lab

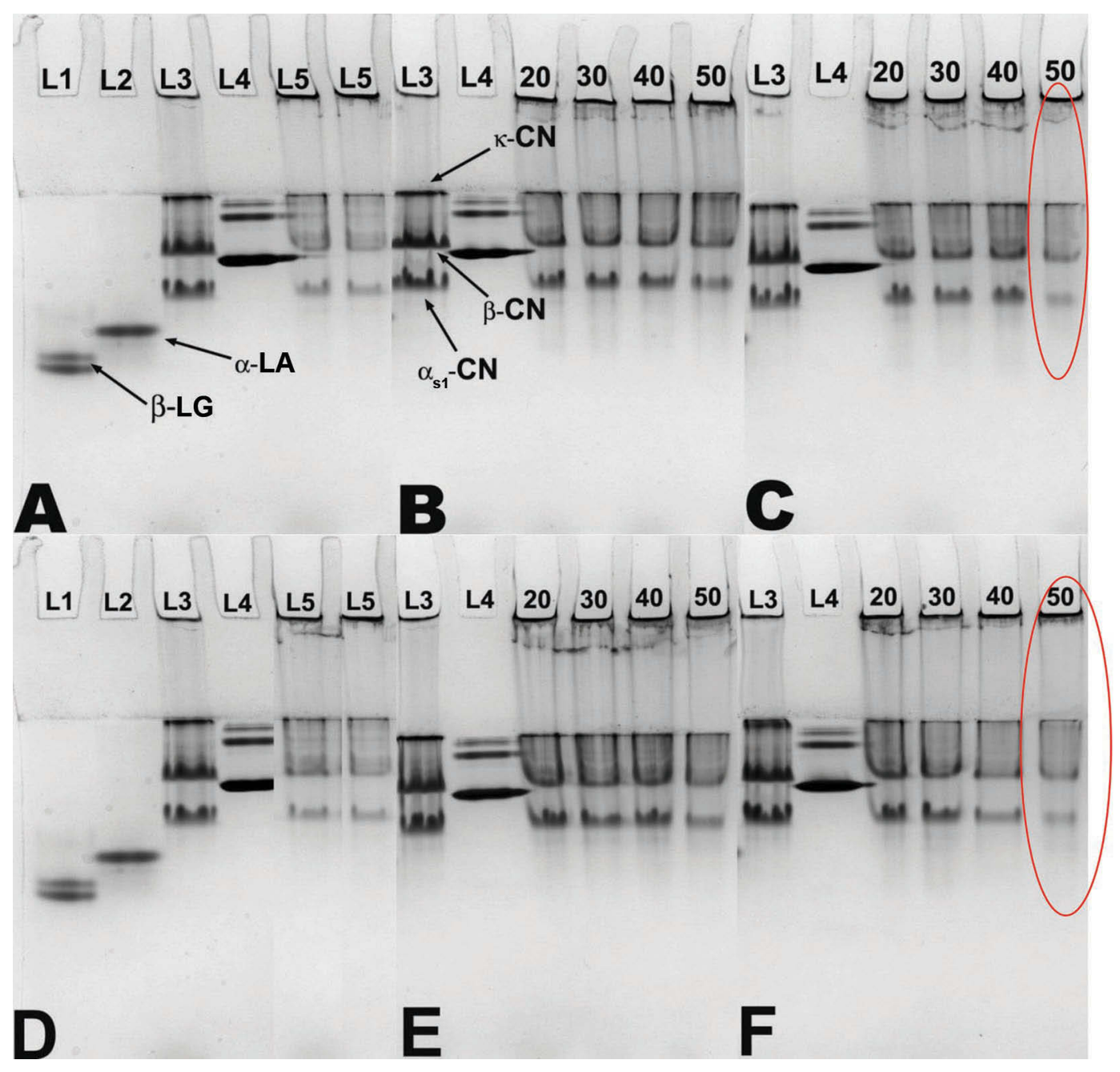

Figure 1. Native-PAGE patterns of UHT skim milk and whole milk on d 0, 14, and 28 of storage. Lanes labeled L1, L2, L3, and L4 represent protein standards of $\beta$-LG, $\alpha$-LA, calcium caseinate, and BSA on d 0, respectively. L5 represents controls: skim milk (A) and whole milk (D). The numbers $20,30,40$, and 50 indicate samples stored at $20,30,40$, and $50^{\circ} \mathrm{C}$ at a given storage time for skim milk (A, B, and C) and whole milk (D, E, and F). Circled lanes indicate accelerated band fading. Color version available online. 
5.2.1 software associated with the densitometer (BioRad Chemidoc MP imaging system). We calculated the absolute quantity of reduced proteins from their respective band intensity, and because the gels were run in duplicate, the absolute quantity was averaged. The average loss in absolute quantity of reduced milk proteins and increase in amount of aggregates obtained at different storage temperature was plotted versus time.

\section{Statistical Analysis}

The experiments were arranged in a block, split plot in time design, with fat content as the main factor and time as a subplot. The design was replicated on a separate occasion, which served as a block. All samples were also subsampled at least twice, giving at least 4 independent observations. The data were analyzed using the GLM procedure of SAS (version 9.1, SAS Institute Inc., Cary, NC). The level of significance was preset at $P<0.05$.

\section{RESULTS AND DISCUSSION}

Changes in protein interactions during the storage of UHT milk under different conditions were demonstrated by alterations in electrophoretic mobility. We explored the type and extent of the interactions at room temperature and at elevated temperatures using native, nonreducing, and reducing SDS-PAGE assays. We identified different bands in patterns by concurrent electrophoresis of standards and by comparing the results with similar reported patterns in the literature (Patel et al., 2007).

\section{Effect of Storage Conditions on Loss of Native Proteins}

The effect of storage time and temperature on nativePAGE patterns in SM and WM is presented in Figure 1. The patterns show thick bands at the entry of stacking gel, corresponding to high-molecular-mass protein aggregates, which were not able to penetrate the gel.

\section{L1 L2 L3 L4 L5 SM SM SM WMWM

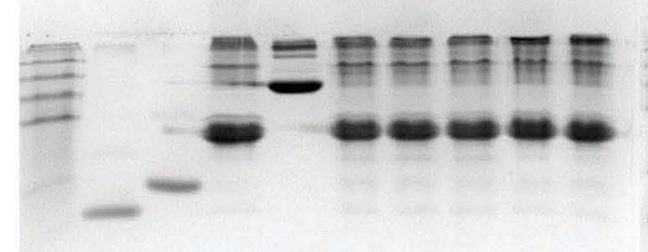

L1 L2 L2 L3 L4 L5 $\underline{20} \underline{30} \underline{40} \underline{50}$

L1 L2 L3 L4 L5 $20 \underline{30} \underline{40} \underline{50}$
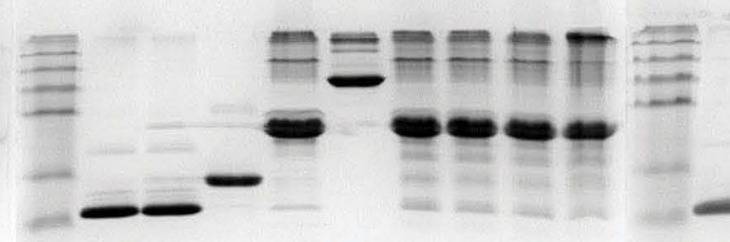

Control

SM-14day

L1 L2 L3 L4 L5 SM SM SM WMWM

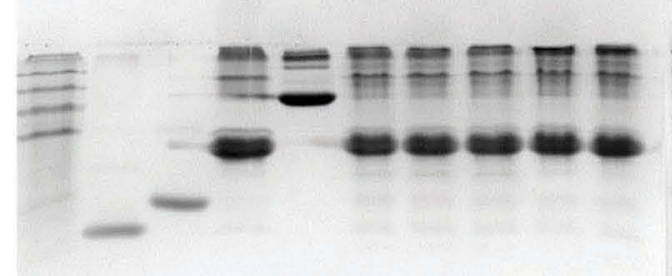

Control
L1 L2 L3 L4 $\quad$ L5 $20 \quad 30 \quad 30 \quad 50$

L1 L2 L3 L4 L5 20

SM-28day

L1 L2 L3 L4 L5 $20 \quad 30 \quad 40 \quad 50$

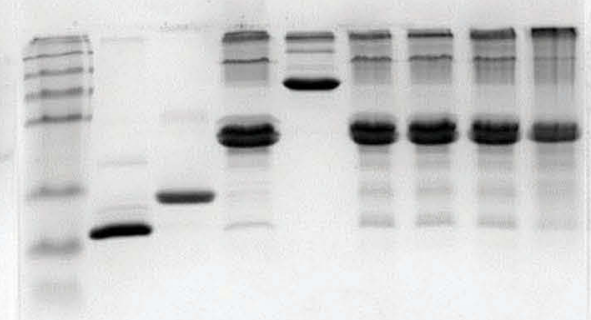

WM-14day

\section{WM-28day}

Figure 2. Nonreducing SDS-PAGE patterns of UHT skim milk (SM) and whole milk (WM) on d 0 (control), 14, and 28 of storage. Lanes labeled L1, L2, L3, L4, and L5 represent a molecular weight marker and protein standards for $\alpha-\mathrm{LA}, \beta-\mathrm{LG}$, calcium caseinate, and BSA, respectively. Skim milk and whole milk samples were stored at d 0 , and $20,30,40$, and 50 denote samples stored at $20,30,40$, and $50^{\circ} \mathrm{C}$ at a given storage time. Circled lanes indicate accelerated fading and aggregation. Color version available online. 

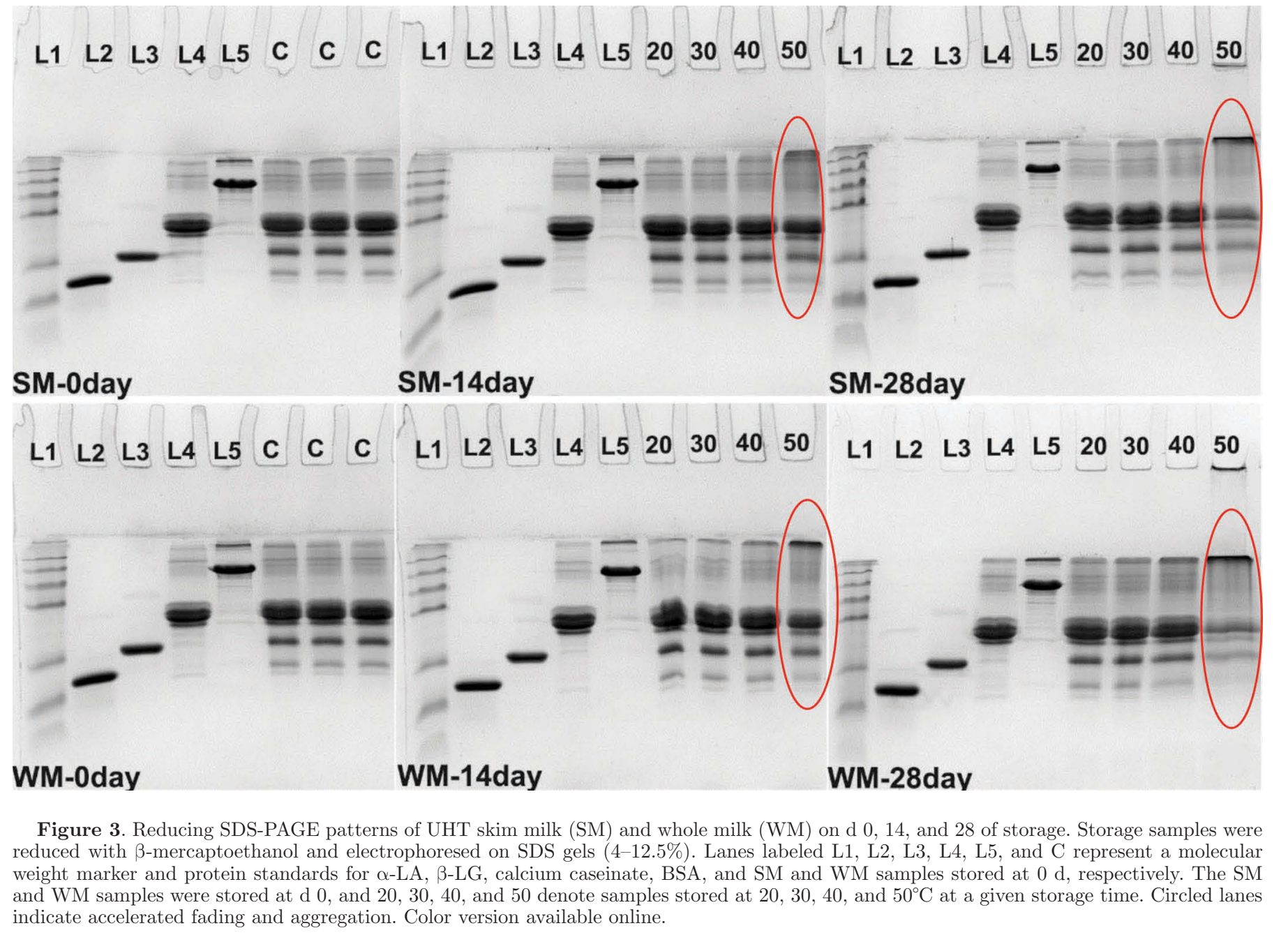

Aggregates probably corresponded to denatured whey proteins associated with themselves and with caseins via thiol-disulfide exchange (Guyomarc'h et al., 2003; Anema, 2008), noncovalent interactions (Donato and Guyomarc'h, 2009), or covalent interactions (Al-Saadi et al., 2013). Faint bands corresponding to native-like whey proteins - namely, $\alpha$-LA and $\beta$-LG, further supported this suggestion. Patterns also exhibited bands corresponding to native $\kappa-\mathrm{CN}, \beta-\mathrm{CN}$, and $\alpha_{\mathrm{S}_{1}} \mathrm{CN}$. We observed a diffusely stained region between $\kappa-\mathrm{CN}$ and $\beta$-CN bands, which has been attributed previously to crosslinked milk proteins (Patel et al., 2007). NativePAGE patterns in both SM and WM at the start of storage (d 0) appeared to be similar (Figures 1A and D). However, we observed more prominent changes between these samples during storage, depending on the storage temperature.

Storage of SM and WM at 20,30 , or $40^{\circ} \mathrm{C}$ for $14 \mathrm{~d}$ did not alter the intensity of the bands corresponding to individual native-like caseins (Figures $1 \mathrm{~B}$ and
1E). However, after $28 \mathrm{~d}$ of storage at the same temperatures, the intensity of all native protein bands appeared to decrease for both SM and WM (Figures 1C and F). Notably, loss in "native-like" band intensities of individual milk proteins appeared to be higher in WM at $40^{\circ} \mathrm{C}$ after $28 \mathrm{~d}$ than in SM. This could be due to liquefaction of milk fat around $40^{\circ} \mathrm{C}$ (MacGibbon and Taylor, 2006). Fat globules are surrounded by caseins and whey proteins upon homogenization, and when melted, they may act as a "glue" between adjacent proteins, increasing the proteins' chance of interaction. A similar observation has been made for the lower heat stability of homogenized milk (Huppertz, 2016) because of the predominant presence of a casein fraction on homogenized fat globules, increasing a volume fraction of casein micelles and enhancing casein particles' rate of encounter, leading to enhanced heatinduced coagulation. Another proposed mechanism driving these changes is oxidation of lipids at elevated storage temperatures. The intermediates (e.g., free 
radicals and hydroperoxides) and end products (e.g., malondialdedyde) from lipid peroxidation interact with AA residues such as cysteine, lysine, histidine, valine, methionine, and phenylalanine, resulting in protein crosslinks (Singh, 1991; Le et al., 2011). In addition to changes in the physical state of lipids and greater generation of the products of lipid oxidation, promoting protein aggregation at higher temperatures, other bulk physiochemical changes (including decline in $\mathrm{pH}$ and increase in ionic calcium activity) could also have contributed to the observed differences in native-PAGE patterns for SM and WM (Boumpa et al., 2008). The effect of fat content on ionic calcium activity and its subsequent effect on protein interactions during storage is not known at present and requires further elaboration.

Although only WM indicated accelerated aggregation of milk proteins at $40^{\circ} \mathrm{C}$, native-PAGE patterns for both $\mathrm{SM}$ and $\mathrm{WM}$ samples stored at $50^{\circ} \mathrm{C}$ were substantially different from those at other temperatures. After $14 \mathrm{~d}$ of storage at $50^{\circ} \mathrm{C}$ in both $\mathrm{SM}$ and $\mathrm{WM}$, bands corresponding to $\beta$-LG and $\alpha$-LA completely disappeared, with a concomitant decrease in intensity of $\alpha_{\mathrm{S}_{1}} \mathrm{CN}, \kappa-\mathrm{CN}$, and $\beta-\mathrm{CN}$ bands (Figures $1 \mathrm{~B}$ and $\mathrm{E}$ ). The intensity of the diffuse region between $\kappa-\mathrm{CN}$ and $\beta-\mathrm{CN}$ bands also diminished. The complete disappearance of bands corresponding to $\beta$-LG and $\alpha$-LA indicated greater reactivity of whey proteins in the formation of aggregates. This was likely caused by denaturation of $\beta-\mathrm{LG}$ and $\alpha-\mathrm{LA}$ and exposure of lysine residues to a high level in these proteins. These characteristics render them a preferable reactant for lactosylation over caseins (Le et al., 2011). Lactosylated whey proteins may further be converted to AMP at higher storage temperatures, which then also crosslink caseins and result in loss of native-like caseins (Le et al., 2011). Further fading out of bands occurred after $28 \mathrm{~d}$ of storage, indicating even greater crosslinking of proteins and at a far higher rate than at other storage temperatures in both SM and WM (Figure $1 \mathrm{C}$ and $\mathrm{F}$ ). As well as increasing concentrations of AMP, higher storage temperatures also accelerate other protein crosslinks through intermediates and end products of lipid oxidation (predominantly in WM), dehydroalanine and hydrophobic or other noncovalent interactions (Singh, 1991; Holland et al., 2011). Dehydroalanine is produced by heat-induced elimination of phosphate from phosphoserine residues in caseins. It then reacts with the amino group of lysine residues, the imidazole group of histidine, or the thiol group of cysteine, resulting in intra- or intermolecular lysinoalanine, histidinoalanine, or lanthionine crosslinks, respectively (O'Connell and Fox, 2003). Higher storage temperature also induces changes in the secondary structure of milk proteins (Mahler et al., 2009). This results in the exposure of hydrophobic regions, which may associate via noncovalent interactions (Andrews, 1975; Henle et al., 1996; Donato and Guyomarc'h, 2009; Holland et al., 2011).

\section{Effect of Storage Temperature on Loss of SDS Monomeric Proteins}

To obtain information regarding the type of aggregation (covalent and noncovalent) and the involvement of particular milk proteins, we further analyzed milk samples using the dissociating agent SDS without the reducing agent. We know that SDS dissociates intermolecular and intramolecular aggregates that are noncovalently linked. Thus, nonreducing SDS-PAGE could reveal the involvement of hydrophobic interactions in the formation of the high-molecular-mass aggregates observed in native-PAGE patterns.

Figure 2 shows SDS-PAGE nonreducing patterns for both SM and WM. These patterns showed intense bands corresponding to monomeric $\alpha_{\mathrm{S}_{1}} \mathrm{CN}, \kappa-\mathrm{CN}$, and $\beta-\mathrm{CN}, \alpha_{\mathrm{S} 2}-\mathrm{CN}$ dimer and BSA. Bands corresponding to SDS monomeric $\alpha-\mathrm{LA}$ and $\beta-\mathrm{LG}$ were faint but had a higher intensity than native bands, implying that these proteins were linked via noncovalent interactions in addition to disulfide or other covalent bonds (Havea et al., 1998; Donato and Guyomarc'h, 2009). Reduction in the intensity of high-molecular-mass aggregates at the top of the stacking gel further supported this suggestion (Figures 1 and 2). However, noticeable bands corresponding to high-molecular-mass aggregates and diffuse regions at the top of the stacking gel and resolving gel, respectively (Figure 2), indicated that these aggregates were either disulfide-linked or covalently bonded. Furthermore, SDS-PAGE patterns of SM and WM at the start of storage were similar (Figure 2), suggesting that the effect of UHT treatment was independent of fat content. This finding contradicted the theory that milk fat protects other components of milk from heat-induced changes (Pellegrino, 1994). However, the effect of fat content appeared to be more relevant during storage at different temperatures.

At and below $40^{\circ} \mathrm{C}$, storage for the first $14 \mathrm{~d}$ did not change the intensity of protein bands in SM (Figure 2). However, in WM, the intensity of bands corresponding to whey proteins decreased, with a concomitant increase in the intensity of aggregate bands at the top of the resolving gel. This was in line with similar observations made in native-PAGE patterns of WM after $14 \mathrm{~d}$ of storage at $40^{\circ} \mathrm{C}$, implying the likely involvement of fat. After $28 \mathrm{~d}$ of storage for SM and WM at 20, 30 , and $40^{\circ} \mathrm{C}$, we observed a decrease in the intensity 
of different SDS monomeric bands (Figure 2). Thus, covalent crosslinking of proteins progressed at a slower rate, even at lower storage temperatures (Gaucher et al., 2008). However, in WM, the bands corresponding to whey proteins were diffuse and faint compared with $\mathrm{SM}$ at the same temperature. The decrease in band intensity of whey proteins was further exacerbated in $\mathrm{WM}$ at $50^{\circ} \mathrm{C}$. After $28 \mathrm{~d}$ of storage at this temperature, whey protein bands disappeared, and we were able to observe only a diffuse region (smear) with very faint bands corresponding to high-molecular-mass protein aggregates $\alpha_{S_{1}}-\mathrm{CN}$ and $\beta$-CN in WM (Figure 2). This diffuse region has been attributed to nondisulfide covalent crosslinking of proteins (Singh, 1991). Skim milk also exhibited an intense aggregate band at the top of the resolving gel and faint bands corresponding to $\beta-\mathrm{CN}, \alpha_{\mathrm{S1}^{-}} \mathrm{CN}$, and whey proteins at $50^{\circ} \mathrm{C}$. The faster and more complete disappearance of whey proteins in WM at and above $40^{\circ} \mathrm{C}$ could be due partly to enhanced covalent crosslinking stemming from changes in the physical state of fat and the oxidation of lipids. Also, other unexplored mechanisms involving changes in $\mathrm{pH}$ or mineral balance differing affected by the presence of fat might have resulted in the different electrophoretic patterns observed for WM.

Only $\alpha_{\mathrm{S} 1}-\mathrm{CN}$ and $\beta-\mathrm{CN}$ were present in both $\mathrm{SM}$ and $\mathrm{WM}$ in SDS-PAGE nonreduced at $50^{\circ} \mathrm{C}$ after $28 \mathrm{~d}$; this could be due to their comparatively higher amounts in milk (Huppertz, 2013). Furthermore, because of their more hydrophobic nature and lack of cysteine residues, $\alpha_{\mathrm{S} 1}-\mathrm{CN}$ and $\beta-\mathrm{CN}$ may be more prone to involvement in noncovalent interactions than other caseins.

\section{Effect of Storage Conditions on Loss of Reduced Proteins}

We further explored the nature of the aggregates and smear (disulfide or other type of covalently bonded) produced at higher temperatures in SDS-PAGE nonreducing patterns by using SDS-PAGE under reducing conditions. The SDS dissociated hydrophobic interactions and, with the addition of $\beta$-mercaptoethanol, it reduced disulfide bonds. Hence, the bands corresponding to aggregates in SDS-PAGE reducing patterns would be entirely due to nondisulfide covalent interactions.

Skim milk and WM had similar patterns on $\mathrm{d} 0$ for native-PAGE and SDS-PAGE nonreducing patterns (Figures 1 to 3 ). This finding reconfirmed previous observations that the effect of UHT treatment on the electrophoretic mobility of milk proteins was independent of fat content. At the beginning of storage, high-molecular-mass aggregates were not present on top of the stacking gel (Figure 3). Only a faint band demonstrative of nonreducible protein aggregates were present at the top of the resolving gel, as shown earlier for nonreducing SDS-PAGE. Furthermore, patterns on d 0 had intense bands corresponding to caseins, $\beta$-LG and $\alpha$-LA, suggesting that thiol-disulfide exchange and hydrophobic interactions were major aggregation pathways at the beginning of storage (Pizzano et al., 2012). We also observed a diffuse region between the nonreducible aggregate band and the $\alpha_{\mathrm{S}_{2}} \mathrm{CN}$ dimer, and between BSA and the $\alpha_{\mathrm{S}^{2}} \mathrm{CN}$ dimer. This region probably also had nondisulfide, covalently linked caseins and whey proteins, because it was present in native-PAGE and in nonreducing SDS-PAGE patterns. It appeared that at the beginning of storage, the order of interactions in both SM and WM was disulfide > noncovalent > covalent (nondisulfide). Although SM and WM had similar patterns on d 0 , storage conditions affected them differently in the context of extent of aggregation and loss of different individual milk proteins.

\section{Kinetics of Aggregate Formation}

Skim milk did not exhibit an increase in the amount of nonreducible and high-molecular-mass aggregates after $28 \mathrm{~d}$ of storage at $20^{\circ} \mathrm{C}$ (Figures 3 and 4 ). However, after $28 \mathrm{~d}$ of storage at 30 and $40^{\circ} \mathrm{C}$, we did note an increase in nonreducible aggregates, although not in high-molecular-mass aggregates. In WM, the trend was slightly different: the nonreducible aggregates started to build up only after $14 \mathrm{~d}$ of storage at 20,30 , or $40^{\circ} \mathrm{C}$. However, like SM, WM showed no apparent increase in the concentration of high-molecular-mass aggregates, even after $28 \mathrm{~d}$ of storage (Figures 3 and 6 ). At $50^{\circ} \mathrm{C}$, the amount of nonreducible and high-molecular-mass aggregates increased to a great extent in both SM and WM (Figure 4). The proteins were most likely aggregated by covalent interactions to form high-molecularmass aggregates, and rate of these interactions was enhanced sharply above $40^{\circ} \mathrm{C}$. Furthermore, the extent of formation of high-molecular-mass aggregates was greater in WM than in SM following $28 \mathrm{~d}$ of storage (Figure 4), suggesting enhanced protein aggregation at higher temperatures in the presence of fat.

Besides the difference in the amounts of aggregates formed, SM and WM also differed by how individual caseins and whey proteins participated in the formation of covalently bound aggregates. In $\mathrm{SM}$ at $20^{\circ} \mathrm{C}$, we observed no change in the quantity of whey proteins and caseins (Figure 5A), supporting our earlier observation that there was no change in reducible and high-molecular-mass aggregates (Figures 3, 4A). In SM at 30 and $40^{\circ} \mathrm{C}, \alpha_{\mathrm{S}_{2}}-\mathrm{CN}, \beta-\mathrm{CN}$, and $\beta$-LG decreased during the first $14 \mathrm{~d}$ of storage, followed by $\alpha_{\mathrm{S} 2}-\mathrm{CN}$ 
and $\alpha$-LA during the next $14 \mathrm{~d}$ of storage (Figures 5B and $\mathrm{C}$ ). However, in $\mathrm{WM}$, the reduction in the quantity of proteins started at $20^{\circ} \mathrm{C}$ (Figures $6 \mathrm{~A}$ to $\mathrm{C}$ ). At 20 , 30 , and $40^{\circ} \mathrm{C}, \beta-\mathrm{LG}$ was one of the first proteins to initiate nondisulfide aggregation in WM, as evidenced by its decrease in concentration after the first $14 \mathrm{~d}$ of storage (Figures 6A to $\mathrm{C}$ ). A reduction in the quantity of $\alpha_{\mathrm{S}^{-}} \mathrm{CN}, \alpha_{\mathrm{S}^{2}} \mathrm{CN}$, and $\beta-\mathrm{LG}$ in WM was evident over the next $14 \mathrm{~d}$ at 20 and $30^{\circ} \mathrm{C}$ (Figures $6 \mathrm{~A}$ and $\mathrm{B}$ ). At $40^{\circ} \mathrm{C}, \alpha$-LA also participated in aggregation through nondisulfide covalent interactions in WM, similar to SM. Loss in the quantity of proteins was much higher at $50^{\circ} \mathrm{C}$ than at 20,30 , or $40^{\circ} \mathrm{C}$ in both $\mathrm{SM}$ and WM. In addition, $\kappa-\mathrm{CN}$ participated in covalent aggregation only in the latter half of storage at $50^{\circ} \mathrm{C}$ in both WM and SM, overruling proteolysis by bacterial proteinases.
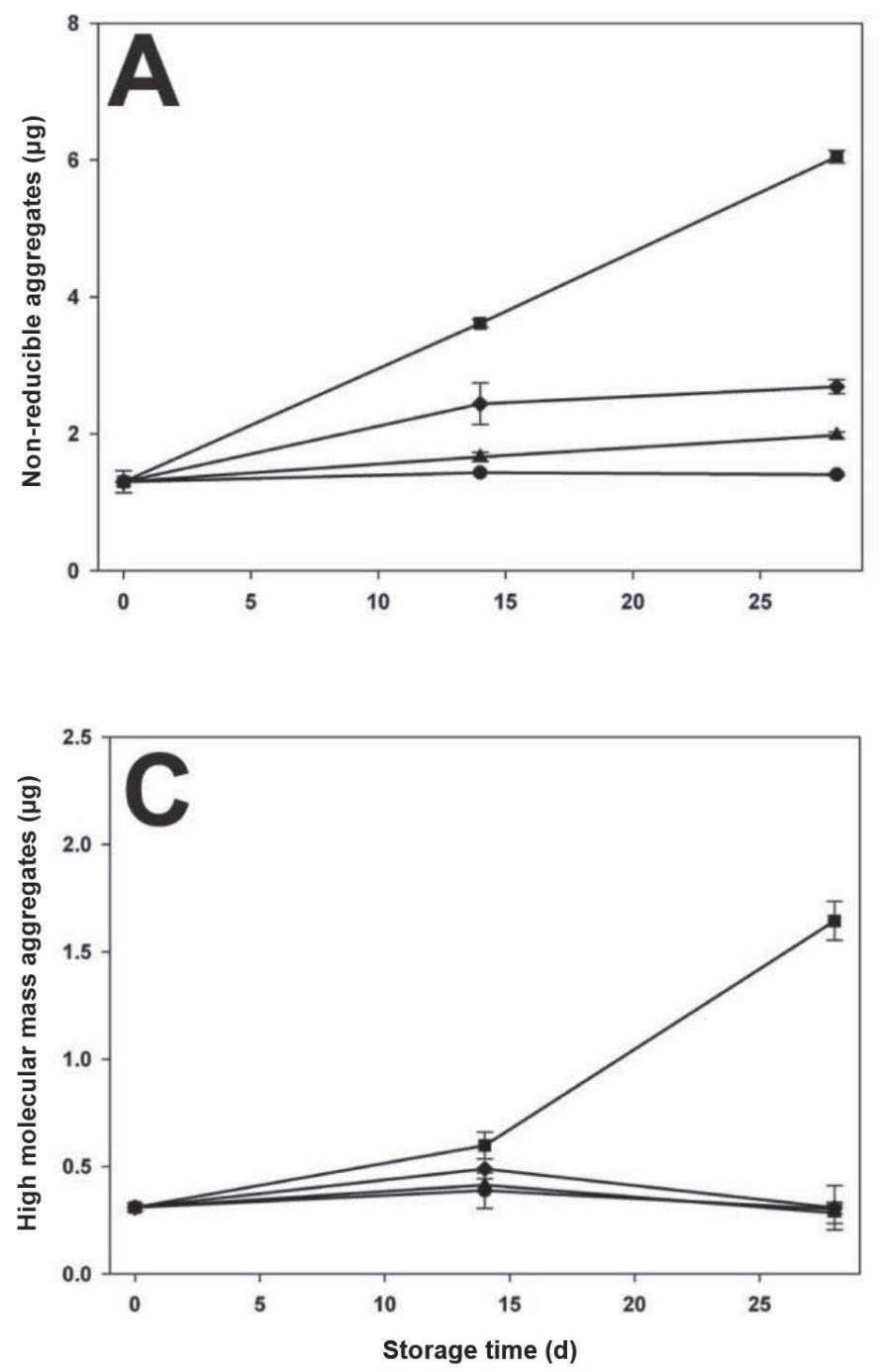

All the proteins in milk seemed to be actively involved in crosslinking at $50^{\circ} \mathrm{C}$. Higher storage temperatures increase intra-micellar crosslinking, which might result in increased electrostatic repulsion inside the micelle and lead to dissociation and sedimentation of crosslinked proteins (Nieuwenhuise and van Boekel, 2003). However, $\beta-\mathrm{CN}$ and $\alpha_{\mathrm{S}^{2}} \mathrm{CN}$ were main players in SM, whereas $\alpha_{\mathrm{S}_{1}} \mathrm{CN}, \alpha_{\mathrm{S} 2} \mathrm{CN}$, and $\alpha$-LA were central to protein-protein interactions in WM (Figures 5 and 6). The difference in type of caseins involved in WM and SM at different temperatures suggested preferences for specific pathways of covalent (nondisulfide) crosslinking.

Nondisulfide covalent crosslinking in UHT milk during storage occurs via AMP, dehydroalanine, and lipid oxidation products (in WM) (Singh, 1991; Le et al., 2011). Crosslinking via AMP involves lactosylation of
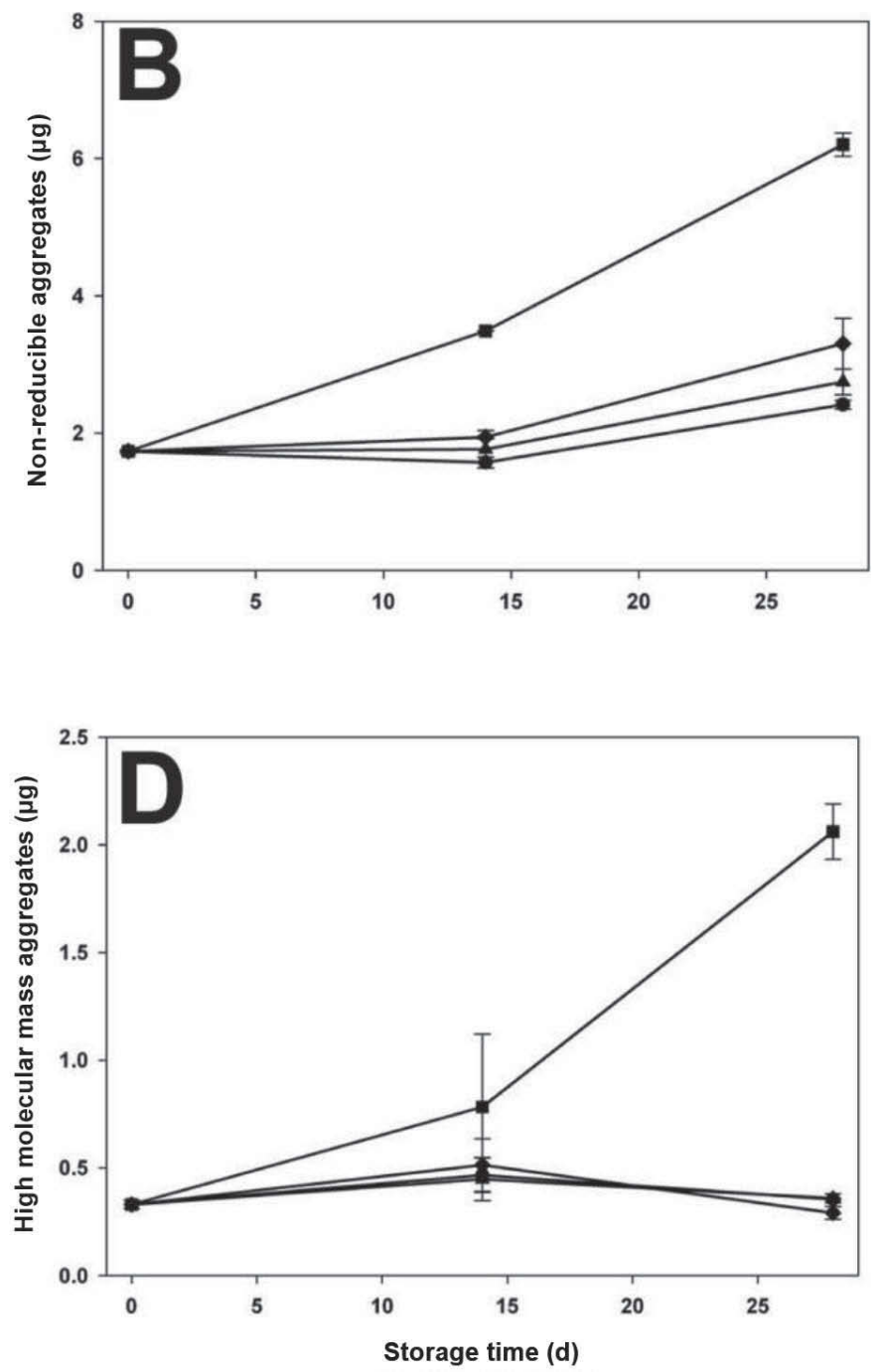

Figure 4. Change in absolute quantity of nonreducible (A and B) and high-molecular-mass $(\mathrm{C}$ and D) aggregates during storage of UHT skim milk (A, C) and whole milk (B, D) at storage temperatures of $20^{\circ} \mathrm{C}(\bullet), 30^{\circ} \mathrm{C}(\boldsymbol{\Delta}), 40^{\circ} \mathrm{C}(\bullet)$, and $50^{\circ} \mathrm{C}(\boldsymbol{\square})$, as obtained from image analysis of reducing SDS-PAGE. Error bars represent SD. 

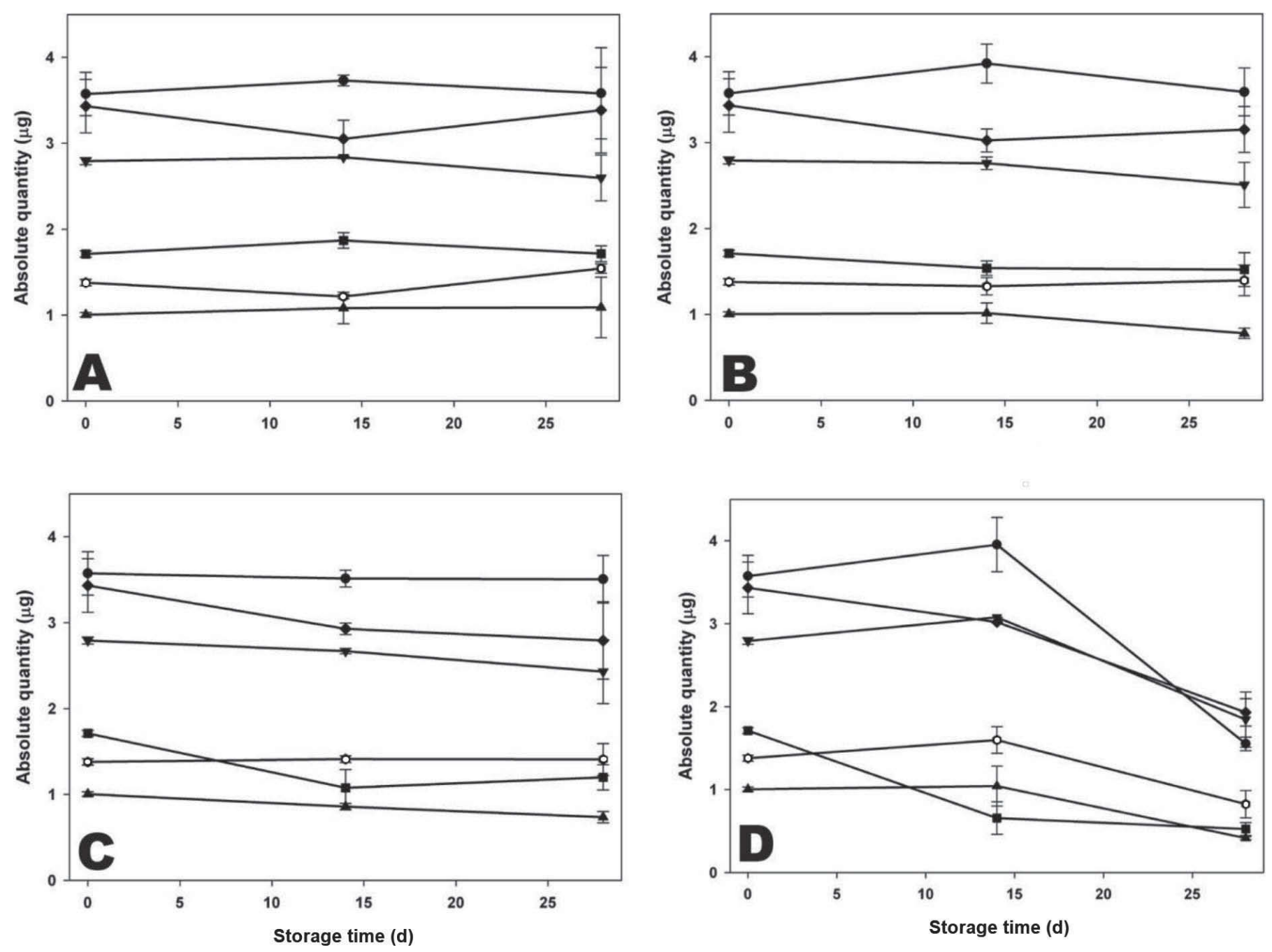

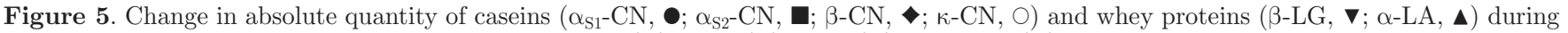
storage of UHT skim milk at storage temperatures of $20^{\circ} \mathrm{C}(\mathrm{A}), 30^{\circ} \mathrm{C}(\mathrm{B}), 40^{\circ} \mathrm{C}(\mathrm{C})$, and $50^{\circ} \mathrm{C}(\mathrm{D})$, as obtained from image analysis of reducing SDS-PAGE. Error bars represent SD.

lysine residues as the first step (Van Boekel, 1998), implying that proteins with a higher number of lysine residues would be preferentially involved in this reaction. The lysine content of different milk proteins vary, following this order: $\alpha_{\mathrm{S}^{-}} \mathrm{CN}>\beta-\mathrm{LG}>\alpha_{\mathrm{S}^{-}} \mathrm{CN}>\alpha-\mathrm{LA}$ $>\beta-\mathrm{CN}>\kappa-\mathrm{CN}$ (Huppertz, 2013). Involvement of $\alpha_{\mathrm{S}^{-}}$ $\mathrm{CN}$ as one of the major players in covalent aggregation in SM (Figure 5) indicates higher levels of AMPmediated crosslinking. Additionally, disappearance of $\alpha$-LA in $\mathrm{SM}$ even at $30^{\circ} \mathrm{C}$ also suggests a higher rate of Maillard reaction in the former. The preference of $\alpha-\mathrm{LA}$ for reaction with lactose was demonstrated earlier by lactosylation of almost all its lysine residues during storage of UHT milk (Holland et al., 2011). Moreover, $\alpha$-LA may also preferentially engage in this reaction (Le et al., 2011) because of conformational changes and denaturation that take place during UHT treatment (Losito et al., 2010). The greater extent of Maillard reaction in SM is also supported by the comparatively higher increase in the "b" value of color in SM than WM at temperatures above $30^{\circ} \mathrm{C}$ (data not shown). Valero et al. (2001) had also reported higher levels of Maillard products in SM than WM during storage. Greater AMP-mediated crosslinking in SM also explained the reduction in quantity of $\beta-\mathrm{CN}$ in SM. Lactosylation results in increased hydrophilicity of the casein micelle interior, which might have weakened hydrophobic associations (Rauh et al., 2015) and released $\beta$-CN to the solution (Figure 7A). In addition to lactosylation, $\alpha_{\mathrm{S} 2^{-}} \mathrm{CN}$ also appears to be most reactive candidate for dehydroalanine-linked proteins, because of a high number of phosphoserine residues and the presence of 2 
cysteine residues (O'Mahony and Fox, 2013). Skim milk with greater involvement of $\alpha_{\mathrm{S}^{2}} \mathrm{CN}$ and $\beta-\mathrm{CN}$ implied a higher rate of AMP and dehydroalanine-mediated crosslinking (Figure 7A).

In $\mathrm{WM}, \alpha_{\mathrm{S}^{-}} \mathrm{CN}, \alpha_{\mathrm{S}^{2}} \mathrm{CN}$, and $\alpha-\mathrm{LA}$ were the main proteins involved in nondisulfide covalent crosslinking (Figure 6). Previous reports have shown $\alpha_{S_{1}-} \mathrm{CN}$ to be the most abundant protein in aggregates (Holland et al., 2011). Furthermore, the higher amount of aggregates in WM than in SM can be attributed to crosslinking via lipid oxidation products and melted fat globules, at and above $40^{\circ} \mathrm{C}$ in WM. The modified fat globule membrane also consists of whey proteins and predominantly caseins besides its native components (Huppertz, 2016). In addition to change in state and
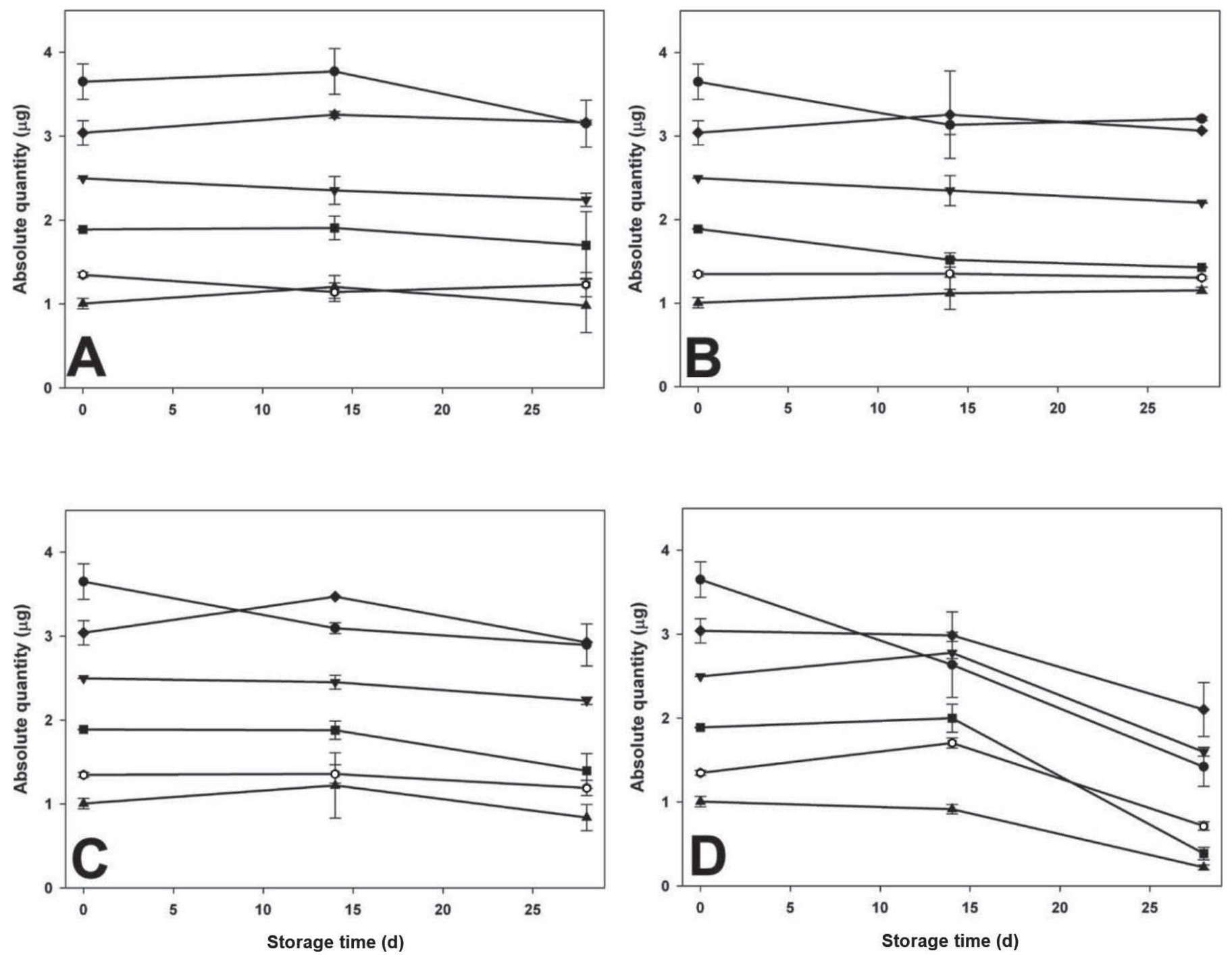

Figure 6. Change in absolute quantity of caseins $\left(\alpha_{\mathrm{S}^{-}} \mathrm{CN}, \boldsymbol{\bullet} ; \alpha_{\mathrm{S} 2}-\mathrm{CN}, \boldsymbol{\square} ; \beta-\mathrm{CN},-<\kappa-\mathrm{CN}, \mathrm{O}\right)$ and whey proteins $(\beta-\mathrm{LG}, \boldsymbol{\nabla} ; \alpha-\mathrm{LA}, \boldsymbol{\Delta})$ during storage of UHT whole milk at storage temperatures of $20^{\circ} \mathrm{C}(\mathrm{A}), 30^{\circ} \mathrm{C}(\mathrm{B}), 40^{\circ} \mathrm{C}(\mathrm{C})$, and $50^{\circ} \mathrm{C}(\mathrm{D})$, as obtained from image analysis of reducing SDS-PAGE. Error bars represent SD. 

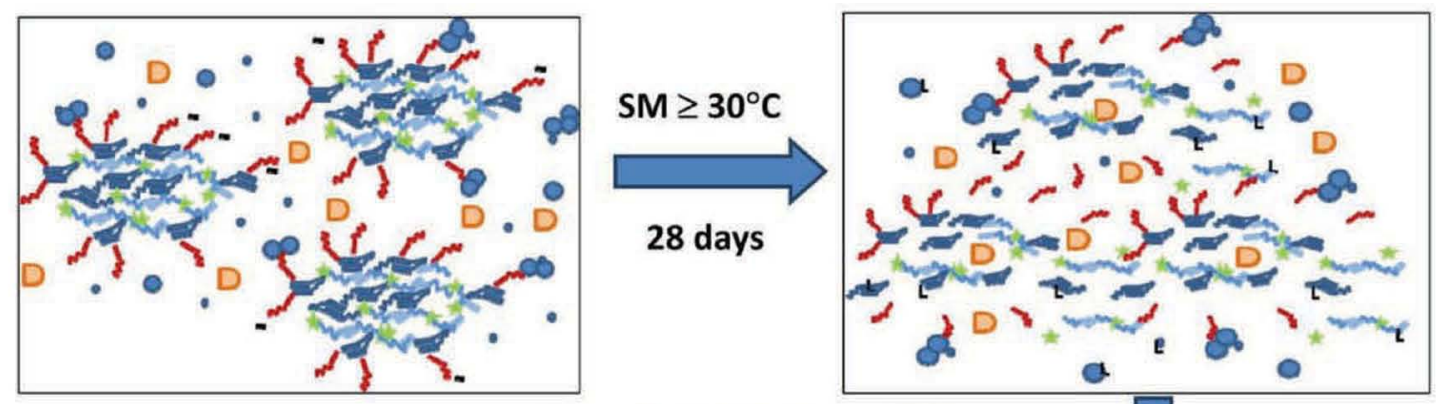

AMP and dehydroalanine mediated protein crosslinking
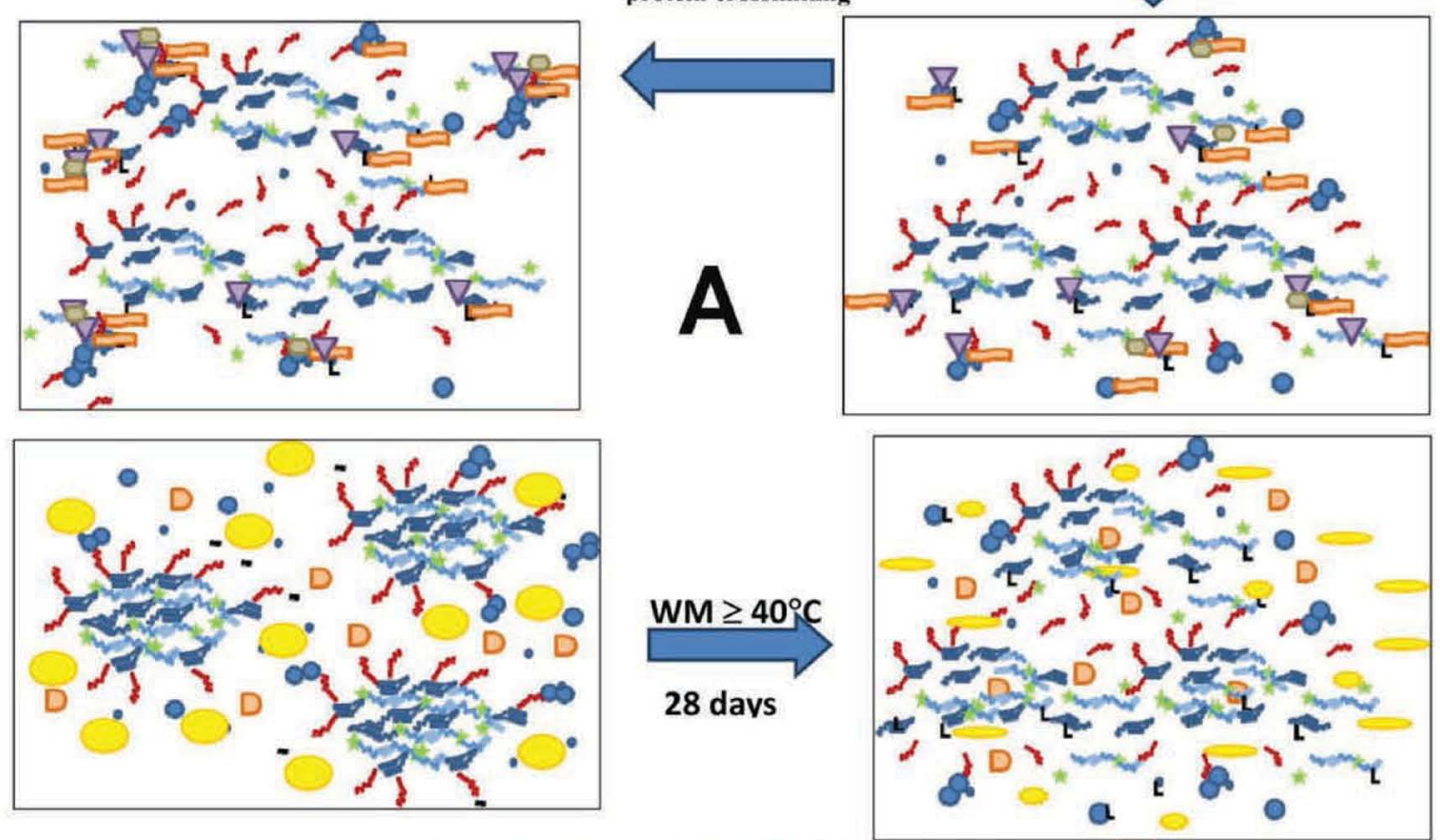

Lipid oxidation products, melted fat, dehydroalanine,
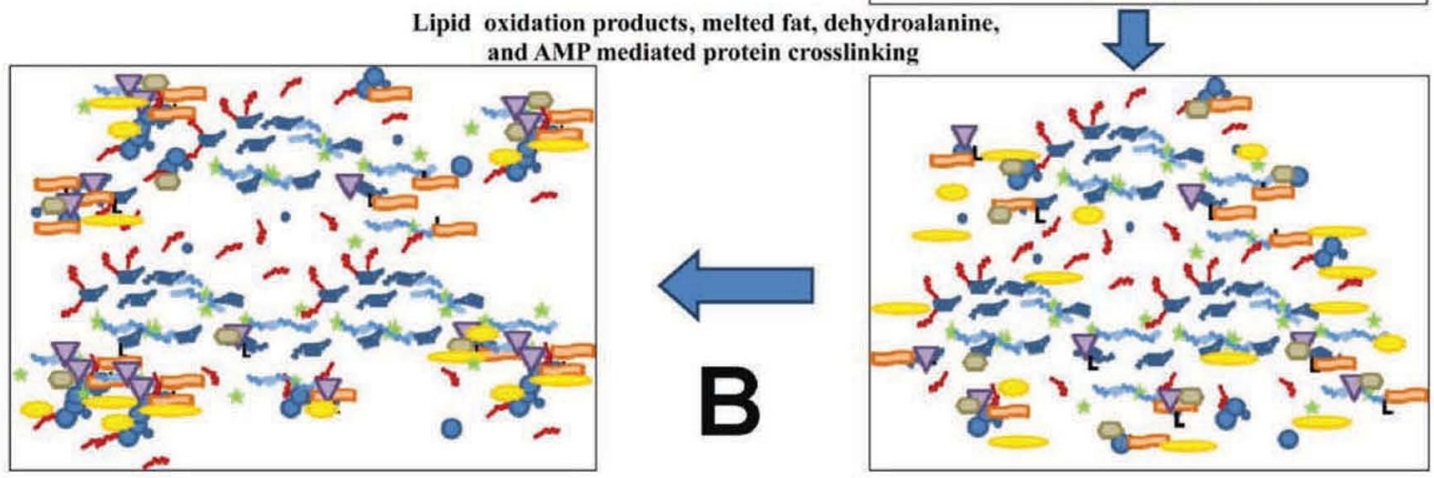

\begin{tabular}{|c|c|c|c|c|c|c|c|}
\hline$\Longrightarrow$ & $\alpha_{\mathrm{s} 1}-\mathrm{CN}$ & $F$ & $\alpha_{s 2}-\mathrm{CN}$ & & $\beta-\mathrm{CN}$ & $-\frac{2}{2}$ & к-CN \\
\hline$\bullet$ & $\alpha$-LA & 0 & $\beta$-LG & $\star \hbar$ & $\mathrm{CCP}$ & $\mathrm{D}$ & Lactose \\
\hline $\mathbf{L}$ & L-lysine & $\nabla$ & AMP & $\square$ & DHA & 8 & AWP \\
\hline & fat globules & 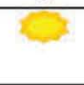 & $\begin{array}{l}\text { oxidized fat } \\
\text { globules }\end{array}$ & $\rightleftarrows$ & $\begin{array}{l}\text { melted fat } \\
\text { globules }\end{array}$ & & \\
\hline 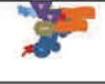 & \multicolumn{3}{|c|}{ crosslinked aggregates } & $y^{2}$ & \multicolumn{3}{|c|}{$\begin{array}{l}\text { crosslinked aggregates plus melted and } \\
\text { oxidized fat }\end{array}$} \\
\hline
\end{tabular}

Figure 7. Advanced Maillard products (AMP), dehydroalanine (DHA), and lipid oxidation products mediated protein crosslinking in (A) skim milk $(\mathrm{SM})$ at and above $30^{\circ} \mathrm{C}$ and $(\mathrm{B})$ whole milk $(\mathrm{WM})$ at and above $40^{\circ} \mathrm{C}$. AWP $=$ aggregated whey proteins; $\mathrm{CCP}=$ colloidal calcium phosphate. Color version available online. 
and that Maillard and dehydroalanine products were the main contributors for the observed changes in UHT SM (Figure 7B). However, these suggestions would require further elaboration.

In conclusion, protein interactions - especially covalent crosslinking - were accelerated at higher storage temperatures. However, at temperatures above $30^{\circ} \mathrm{C}$ in $\mathrm{WM}$ and above $40^{\circ} \mathrm{C}$ in $\mathrm{SM}$, the rate and type of these reactions were very different from those at $20^{\circ} \mathrm{C}$. Especially in case of WM, protein crosslinking appeared to follow a different pathway that may not occur in storage at lower temperatures. In addition, the pathways discussed above that enhance protein interactions were only the major ones and did not include all possible factors, which are numerous because of the complex nature of milk. Extrapolating these reactions to predict changes in protein interactions at lower temperatures is very difficult and emphasizes the need for long-term study. However, acquired knowledge of the involvement of individual proteins and the kinetics of these changes may assist in identifying structural changes that can be determined by a spectral analysis, such as Fourier transform infrared spectroscopy. A detailed long-term study would also need to be undertaken to confirm these changes and establish them as markers for prediction of the shelf life of UHT milk using spectral analysis.

\section{ACKNOWLEDGMENTS}

This work is supported by the Department of Business and Innovation of the Victorian Government, through its Victoria India Doctoral Scholarship Program (managed by the Australia India Institute). The first author also acknowledges her employer, the Indian Council of Agricultural Research, for granting study leave to pursue a $\mathrm{PhD}$.

\section{REFERENCES}

Al-Saadi, J. M., and H. C. Deeth. 2008. Cross-linking of proteins and other changes in UHT milk during storage at different temperatures. Aust. J. Dairy Technol. 63:93-99.

Al-Saadi, J. M. S., A. M. Easa, and H. C. Deeth. 2013. Effect of lactose on cross-linking of milk proteins during heat treatments. Int. Dairy J. 66:1-6.

Andrews, A. 1975. Properties of aseptically packed ultra-high-temperature milk: III. Formation of polymerized protein during storage at various temperatures. J. Dairy Res. 42:89-99.

Andrews, A., and G. Cheeseman. 1972. Properties of aseptically packed ultra-high-temperature milk: II. Molecular weight changes of the casein components during storage. J. Dairy Res. 39:395-408.

Anema, S. G. 2008. The whey proteins in milk: Thermal denaturation, physical interactions and effects on the functional properties of milk. Pages 239-281 in Milk Proteins: From Expression to Food. A. Thompson, M. Boland, and H. Singh, ed. Academic Press, San Diego, CA.

Boumpa, T., A. Tsioulpas, A. S. Grandison, and M. J. Lewis. 2008. Effects of phosphates and citrates on sediment formation in UHT goats' milk. J. Dairy Res. 75:160-166.
Datta, N., and H. C. Deeth. 2001. Age gelation of UHT Milk-A review. Food Bioprod. Process. 79:197-210.

Deeth, H., and M. Lewis. 2016. Protein stability in sterilised milk and milk products. Pages 247-286 in Advanced Dairy Chemistry, Vol. 1B: Proteins, Applied Aspects. 4th ed. P. L. H. McSweeney, S. A. O'Mahony, ed. Springer Sci. Business Media, New York, NY.

Dissanayake, M., L. Ramchandran, C. Piyadasa, and T. Vasiljevic. 2013. Influence of heat and $\mathrm{pH}$ on structure and conformation of whey proteins. Int. Dairy J. 28:56-61.

Donato, L., and F. Guyomarc'h. 2009. Formation and properties of the whey protein/ $\kappa$-casein complexes in heated skim milk-A review. Dairy Sci. Technol. 89:3-29.

Friedman, M. 1999. Chemistry, biochemistry, nutrition, and microbiology of lysinoalanine, lanthionine, and histidinoalanine in food and other proteins. J. Agric. Food Chem. 47:1295-1319.

Garcia-Risco, M. R., M. Ramos, and R. Lopez-Fandino. 1999. Proteolysis, protein distribution and stability of UHT milk during storage at room temperature. J. Sci. Food Agric. 79:1171-1178.

Gaucher, I., D. Mollé, V. Gagnaire, and F. Gaucheron. 2008. Effects of storage temperature on physico-chemical characteristics of semiskimmed UHT milk. Food Hydrocoll. 22:130-143.

Guyomarc'h, F., A. J. Law, and D. G. Dalgleish. 2003. Formation of soluble and micelle-bound protein aggregates in heated milk. J. Agric. Food Chem. 51:4652-4660.

Havea, P., H. Singh, L. K. Creamer, and O. H. Campanella. 1998. Electrophoretic characterization of the protein products formed during heat treatment of whey protein concentrate solutions. J. Dairy Res. 65:79-91.

Henle, T., U. Schwarzenbolz, and H. Klostermeyer. 1996. Irreversibles crosslinking of casein during storage of UHT-treated skim milk. In Proc. Heat Treatments and Alternative Methods, Vienna, Austria. Int. Dairy Fed., Brussels, Belgium.

Holland, J. W., R. Gupta, H. C. Deeth, and P. F. Alewood. 2011. Proteomic analysis of temperature-dependent changes in stored UHT milk. J. Agric. Food Chem. 59:1837-1846.

Huppertz, T. 2013. Chemistry of the caseins. Pages 135-160 in Advanced Dairy Chemistry, Vol. 1A: Proteins, Basic Aspects. P. L. H. McSweeney and P. F. Fox, ed. Springer, New York, NY.

Huppertz, T. 2016. Heat stability of milk. Pages 179-196 in Advanced Dairy Chemistry, Volume 1B: Proteins, Applied Aspects. H. P. L. McSweeney and A. J. O'Mahony, ed. Springer New York, New York, NY.

Kocak, H. R., and J. G. Zadow. 1985. Age gelation of UHT whole milk as influenced by storage temperature. Aust. J. Dairy Technol. 40:14-21.

Le, T. T., B. Bhandari, J. W. Holland, and H. C. Deeth. 2011. Maillard reaction and protein cross-linking in relation to the solubility of milk powders. J. Agric. Food Chem. 59:12473-12479.

López-Fandiño, R., A. Olano, N. Corzo, and M. Ramos. 1993. Proteolysis during storage of UHT milk: differences between whole and skim milk. J. Dairy Res. 60:339-347.

Losito, I., E. Stringano, S. Carulli, and F. Palmisano. 2010. Correlation between lactosylation and denaturation of major whey proteins: An investigation by liquid chromatography-electrospray ionization mass spectrometry. Anal. Bioanal. Chem. 396:2293-2306.

MacGibbon, A. K. H., and M. W. Taylor. 2006. Composition and structure of bovine milk lipids. Pages 1-42 in Advanced Dairy Chemistry, Vol. 2: Lipids. 3rd ed. P. F. Fox and P. L. H. McSweeney, ed. Springer, New York, NY.

Mahler, H.-C., W. Friess, U. Grauschopf, and S. Kiese. 2009. Protein aggregation: Pathways, induction factors and analysis. J. Pharm. Sci. 98:2909-2934.

McMahon, D. J. 1996. Age gelation of UHT milk: Changes that occur during storage, their effect on shelf life and the mechanism by which age gelation occurs. Pages 315-326 in Heat Treatments and Alternative Methods. Int. Dairy Fed., Brussels, Belgium.

Nieuwenhuise, J. A., and M. A. J. S. van Boekel. 2003. Protein stability in sterilised milk and milk products. Pages 947-974 in Advanced Dairy Chemistry, Vol. 1: Proteins. 3rd ed. P. F. Fox and P. L. H. McSweeney, ed. Kluwer Academic/Plenum Publishers, New York, NY. 
O'Connell, J. E., and P. F. Fox. 2003. Heat-induced coagulation of milk. Pages 879-945 in Advanced Dairy Chemistry, Vol. 1: Proteins. 3rd ed. P. F. Fox and P. L. H. McSweeney, ed. Kluwer Academic/Plenum Publishers, New York, NY.

O'Mahony, J. A., and P. F. Fox. 2013. Milk proteins: Introduction and historical aspects. Pages 43-85 in Advanced Dairy Chemistry, Vol. 1A: Proteins, Basic Aspects. 4th ed. P. L. H. McSweeney and P. F. Fox, ed. Springer Science, New York, NY.

Patel, H. A., S. G. Anema, S. E. Holroyd, H. Singh, and L. K. Creamer. 2007. Methods to determine denaturation and aggregation of proteins in low-, medium- and high-heat skim milk powders. Lait $87: 251-268$.

Pellegrino, L. 1994. Influence of fat content on some heat-induced changes in milk and cream. Nederlands melk en Zuivel Tijdschrift 48:71-80.

Pizzano, R., C. Manzo, M. Adalgisa Nicolai, and F. Addeo. 2012. Occurrence of major whey proteins in the $\mathrm{pH} 4.6$ insoluble protein fraction from UHT-treated milk. J. Agric. Food Chem. 60:80448050 .
Rauh, V. M., L. B. Johansen, M. Bakman, R. Ipsen, M. Paulsson, L. B. Larsen, and M. Hammershøj. 2015. Protein lactosylation in UHT milk during storage measured by liquid chromatographymass spectrometry and quantification of furosine. Int. J. Dairy Technol. 68:486-494.

Richards, M., H. L. De Kock, and E. M. Buys. 2014. Multivariate accelerated shelf-life test of low fat UHT milk. Int. Dairy J. 36:38-45.

Samel, R., R. W. V. Weaver, and D. B. Gammack. 1971. Changes on storage in milk processed by ultra-high-temperature sterilization. J. Dairy Res. 38:323-332.

Singh, H. 1991. Modification of food proteins by covalent crosslinking. Trends Food Sci. Technol. 2:196-200.

Valero, E., M. Villamiel, B. Miralles, J. Sanz, and I. Martínez-Castro. 2001. Changes in flavour and volatile components during storage of whole and skimmed UHT milk. Food Chem. 72:51-58.

Van Boekel, M. 1998. Effect of heating on Maillard reactions in milk. Food Chem. 62:403-414.

Wang, W., S. Nema, and D. Teagarden. 2010. Protein aggregationPathways and influencing factors. Int. J. Pharm. 390:89-99. 